"The Professional Development of Graduate Students in Economics"

by

KimMarie McGoldrick

Gail Hoyt

and

David Colander

July 2008

MIDDLEBURY COLLEGE ECONOMICS DISCUSSION PAPER NO. 08-11

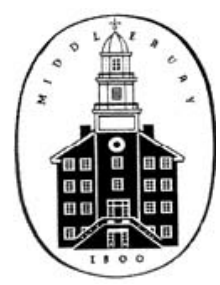

DEPARTMENT OF ECONOMICS

MIDDLEBURY COLLEGE

MIDDLEBURY, VERMONT 05753

http://www.middlebury.edu/ econ 


\title{
The Professional Development of Graduate Students in Economics ${ }^{1}$
}

\author{
July 2008 \\ KimMarie McGoldrick \\ Department of Economics \\ University of Richmond \\ Richmond, VA 23173 \\ Tel: 804-289-8575 \\ kmcgoldr@richmond.edu \\ Gail Hoyt \\ Department of Economics \\ 335D Gatton Business \& Econ. Bldg. \\ University of Kentucky \\ Lexington, KY 40506-0034 \\ Tel: 859-257-2517 \\ ghoyt@popuky.edu \\ David Colander \\ Department of Economics \\ Middlebury College \\ Middlebury VT 05753 \\ Tel: 802-443-5302 \\ colander@middlebury.edu
}

\begin{abstract}
This paper provides insight into the skill development activities of graduate students at U.S. institutions providing graduate education in economics. It documents the extent of student participation in and preparation for research and teaching activities while in graduate school. Over fifty percent of students are involved in teaching related activities including grading, leading recitation sections, and teaching their own sections with and without guidance. Most were generally satisfied with their preparation. About fifty-five percent of graduate students attend economic conferences, twenty percent present papers, twenty-two percent submit papers and ten percent have published. Important differences by assistantship assignments, institutional rank, and gender in such activities are highlighted. Findings suggest that programs could do more to prepare students for participation in professional activities post graduation.
\end{abstract}

\footnotetext{
${ }^{1}$ The authors would like to thank Kenneth Elzinga and participants of the 2006 SEA session on Research in Economic Education for helpful comments on earlier drafts of this paper.
} 
Graduate students have the opportunity to acquire a wide range of teaching and research related skills during their degree programs which enhance their potential performance whether they chose to go into academics, government work, or the private sector. Yet, to what degree are students actually participating in activities that prepare them to teach and do research while in graduate school? This paper reports result of a survey administered to a sample of the student population in U.S. economics graduate programs. The findings reported herein provide insight into the extent to which graduate students are engaged in professional development activities, their satisfaction with their training, and how student's activities matche up with their career goals..

Graduate student training was previously explored by Walstad and Becker (2003) using program level data. They surveyed economics department chairs regarding the degree of graduate student teaching, preparation for teaching activities, and evaluation of graduate teaching, and found that 60 percent of graduate students have some teaching-related responsibilities: about 12 percent teach their own courses; about 28 percent lead a recitation section; and about 20 percent assist professors with their own courses. (p. 450) Department chairs reported a wide range of preparation requirements associated with these teaching activities, ranging from taking preparation courses for graduate credit (25 percent), participating in non credit programs (50 percent), providing assistance for faculty with courses (50 percent), passing comprehensive exams (25 percent), or passing an English-language proficiency exam in the case of international students (80 percent). (p. 451) Over 60 percent of responding department chairs believed that the preparation of their graduate students for teaching was good or very good. (p. 453)

While the majority of department chairs believe their preparatory programs adequately equip their students to teach and do research, the view from the perspective of newly hired faculty is less positive about the teaching and research preparation they received. Stock and Hansen (2004) survey two cohorts of graduate students $(1996,2001)$ to determine the degree of (mis)match between proficiencies and skills emphasized in graduate school and those needed for academic careers. They find that a disconnect exists, with students claiming too little emphasis by their Ph.D. programs with respect to proficiencies of applying economic theory to real world problems, understanding economic institutions and history, and understanding the history of economic ideas. (p. 267) Furthermore, over one third of students surveyed (44 percent in 1996 and 33 percent in 2001 cohorts) report too little emphasis on developing teaching skills in their graduate program. (p. 270) About 70 percent of students surveyed list instruction as the least important skill for success in their graduate program, whereas only 29-38 percent made the same statement about this skill in their current job. (p. 268)

Our survey differs in that it reports the views of students not department chairs on these issues. Specifically, we generate a student level description of the types of teaching-related activities they are assigned, the level of preparation they are provided for teaching and their degree of satisfaction with this level preparation. An additional set of questions targets the type of duties associated with research assistant positions, student satisfaction with preparation for these duties, and the degree to which all graduate students participated in key research-related activities such as conference presentations, journal submissions, and publications. Finally, rankings of students' perceived importance of various skills, including those associated with teaching and research, are gathered along with student career expectations. Results are described 
for the entire sample as well as for comparisons between top and second tier programs and by gender. $^{2}$

\section{Methodology}

U.S. News and World Report (2005) identifies 132 graduate programs in economics in the U.S. After contacting these programs to solicit participation in this study, we found that only 126 of those programs were currently viable PhD programs. ${ }^{3}$ Of the 126 viable programs, 106 programs agreed to participate in this study and surveys were distributed to all students at each of these programs. In order to ensure proper distribution, Directors of Graduate Studies were asked to facilitate the administration of the survey. A letter of introduction was sent requesting that graduate students be directed to the online survey site. Survey management was conducted through Zoomerang, an online survey software instrument. ${ }^{4}$ Students were informed that participation was voluntary and the survey should take approximately 15 minutes. Follow up email and phone communications to department chairs and directors of graduate studies were made to encourage participation. 1,489 students completed the questionnaire, which from a total population of about 12,000 economics graduate students, generates a response rate of 12.6 percent. $^{5}$

\section{Results}

Table 1 provides basic demographic information for the nearly 1,500 complete responses. ${ }^{6}$ The average age of survey respondents is 28 and 64 percent of respondents are male. Caucasian students make up 62 percent of the sample; 14 percent of students are East Asian, 7 percent are Hispanic, and 6 percent are South Asian. 51 percent of graduate students in the sample are U.S. citizens. The gender and racial composition of our sample is generally consistent with previous studies including those reported in a recent survey of Ph.D.-granting departments conducted by Stock, Finnegan, and Siegfried (2006). First year students comprise 24 percent of the sample with second, third, fourth, and fifth and higher making up 24 percent, 18 percent, 16 percent and 19 percent respectively. This decline as year in the program progresses could reflect standard attrition as well as students bunching up in the ABD stage of the degree. Students are involved in a wide range of activities with about half holding teaching assistantships and 31 percent receiving research assistantships ${ }^{7}$. Nearly one-third of students in this sample are working on papers for publication.

\footnotetext{
${ }^{2}$ First and second tier program classifications are based on the ranking of programs included in Thursby (2000). Top tier programs are defined as those in the top 25 in this ranking of which 19 programs have students who participated in the survey.

${ }^{3}$ Schools that were not viable for the sample included schools in New Orleans as the survey was administered shortly after Hurricane Katrina reduced the operations of institutions there. Also, programs like Notre Dame and the University of Texas at Dallas were newly emerging at the time.

${ }^{4}$ The survey was approved by the Instructional Review Board at the University of Richmond and field tested at one institution prior to implementation in October of 2005.

${ }^{5}$ In 2005, 11,805 students were enrolled in economics graduate programs granting masters and/or PhDs (NSF, 2005), which is a slightly larger group than those granting PhDs, the group we tried to capture.

${ }^{6}$ This study makes no claim to be a fully scientific study. No significance tests are reported since the assumptions needed for the significant tests to be significant have not been met, and including such test statistics could make the results more scientific than they in fact are.

${ }^{7}$ Approximately 11 percent of our sample (151 students, 101 male and 50 female) claimed to have both RA and TA positions. These students were subsequently included in both RA and TA samples.
} 
Graduate students at top tier schools make up 37 percent of the respondents. While there are no wide disparities in demographic characteristics across students in top and second tier programs in the sample, top tier students are more likely to be research assistants (RAs), and less likely to be teaching assistants (TAs) or involved in consulting work. On the other hand, there appears to be little difference by gender in the assignment of research and teaching assistant positions. Because females and students in top tier programs are more likely to be in their $5^{\text {th }}$ year or beyond in their program, it is not surprising that both are much more likely to be working on dissertations. However, it is interesting to note, that while top tier students are also more likely to be working on writing papers for publication, women are less likely to be involved in this activity.

Tables 2 and 3 provide detailed information for the 48.5 percent of the full sample holding teaching assistant positions, providing comparisons across cohorts and by duties respectively. ${ }^{8}$ About 22 percent of TAs serve as graders, 41 percent lead recitations, 10 percent teach their own class with some guidance from a faculty member and about 20 percent teach their own class without guidance. ${ }^{9}$ Consistent with Walstad and Becker (2003), we find these duties are reflective of year in graduate school. Graders are most likely to be in their first two years (64 percent) and those who teach their own courses are far more likely to have completed at least two years of graduate school (75 percent for those who teach their own class with guidance and almost 86 percent of TAs who teach their class with faculty without guidance). Results also reveal interesting differences in how schools employ their teaching assistants. Top tier students are much less likely than second tier students to be involved with grading, but much more likely to be leading recitation sections. Second tier students are much more likely to be teaching their own course without the supervision of a faculty member while females are slightly more likely to be engaged in this activity.

While it might be surprising that about 47 percent of TAs say they have had no preparation for the teaching-related duties they perform, it is important to note that this represents all categories of duties and is somewhat misleading as one might not expect graders, for example, to need large amounts of preparation. In fact, the percentage of students claiming no preparation declines for those taking on more sophisticated duties moving from grading, to leading recitations, to teaching their own course with guidance. Over 60 percent of graders claim to have no preparation while only 42 percent of TAs leading recitations and 28 percent of those teaching (with faculty guidance) make similar claims. Not surprisingly, students teaching their own courses without guidance are much more likely to report no preparation. This may simply be reflective of programs choosing the most capable students to teach, necessitating little formal preparation or monitoring.

Consistent with results of Walstad and Becker (2003), students report a range of preparatory requirements associated with their teaching activities. ${ }^{10} 36.7$ percent of TAs

\footnotetext{
${ }^{8}$ Walstad and Becker (2003) indicate that department chairs report $60 \%$ of graduate students are involved in teaching-related activities. (p. 450)

${ }^{9}$ Walstad and Becker (2003) report that of all graduate students in programs (not just ones identified as TAs), 20\% grade, $28 \%$ lead recitations, and $12 \%$ teacher their own classes. (p. 450)

${ }^{10}$ Of the sub sample of programs which employ graduate student instructors, Walstad and Becker (2003) report that 25 percent require a graduate credit course, 50 percent require a non credit teaching program; 50 percent require students to first assist a faculty member, 25 percent have some other requirement, and 80 percent require an ESL test as preparation for teaching.
} 
indicated that English was not their primary language and they were required to take a proficiency test. Nearly one third of all TAs indicated taking some sort of preparatory teaching course with18 percent taking a noncredit teaching course taught by the economics department and about 13 percent taking a course for credit taught by the economics department. Again, comparisons across program rankings and by gender provide important insights. Women were more likely than men to take teaching preparation courses (both for credit and not for credit) and top tier students were much more likely to take a noncredit course than second tier students. A larger percent of female TAs indicated that English was not their first language and they were required to take a proficiency exam, but this is not surprising given the percent of non US citizens in our sample is higher for females than males. Females were also much less likely than males to say they had no preparation, so assuming that departments are not requiring females to have more preparation, it is possible females are more likely to voluntarily participate in training.

Despite the fact that $47 \%$ of TAs say they received no preparation for their duties, they are generally satisfied with their level of preparation; $47 \%$ were very satisfied; $45 \%$ were somewhat satisfied and 8 percent were unsatisfied. Nonetheless, those teaching without guidance are more likely to be unsatisfied and their comments suggest they universally felt underprepared. In comparison, Walstad and Becker (2003) asked department chairs to rate the preparation for teaching that they provide their graduate students. Of the 84 departments in their study, 23 percent indicated the preparation was very good; 38 percent good; 35 percent adequate; and 5 percent poor. (p. 453)

The degree to which teaching-related duties are evaluated increases as the level of sophistication of responsibilities increases, with $97 \%$ of those teaching (combined with and without guidance) having some form of evaluation. End-of-term evaluations are most prevalent, despite oft mentioned concerns about accuracy and potential bias associated with such instruments. Perhaps this form of evaluation still remains the lowest cost and most efficient means of gathering feedback. Less than one third of graduate students who teach their own classes have been observed by a faculty member although $46 \%$ of department chairs maintain that faculty members visit TAs in the classroom (Walstad and Becker, 2003). 48 percent of department chairs surveyed by Walstad and Becker say they review course materials for TAs, but responses from the graduate students in our study suggest this practice is fairly uncommon. Comparisons by institutional ranking and gender provide differences of note. While about 19 percent of second tier students claim to have no formal evaluation of their teaching activities, only about 6 percent of top tier students make the same claim and top tier students are much more likely to be subject to end-of-term evaluations. Also we find that females teaching their own class with guidance are much more likely to be evaluated using each form of evaluation than their male counterparts. ${ }^{11}$

Table 4 summarizes results regarding research-related professional development activities in which graduate students are engaged. Not surprisingly, the level of activity declines as the degree of sophistication increases. About 56 percent of graduate students have attended a professional economics conference and about 46 percent claim to have attended conferences that are not specifically or entirely related to economics. Approximately 37 percent have presented a research paper in a graduate school seminar setting and 21 percent have presented a paper at an

\footnotetext{
${ }^{11}$ Results presented in Table 3 and further broken down by gender and institution ranking are not provided herein due to space constraints. These results are available upon request.
} 
economics conference. About 22 percent of students have submitted papers to economics journals and just less than half of these (about 10 percent) have actually had a paper accepted.

If top tier institutions are more focused on preparing their students for jobs at other top tier institutions, one might expect these students to participate in research related activities to a greater degree. And while top tier students do seem much more likely to present a paper in a seminar setting, across other measures such as attending economics conferences there are less dramatic differences across tiers. One pattern that does appear is the greater participation of students at second tier institutions in activities that do not solely involve economics including attending other types of conferences, submitting papers to non economics journals, and successfully publishing in these journals. This may be an indication of the differences in the type of research conducted at these two types of institutions.

RAs in our sample perform a wide range of duties including locating and summarizing relevant literature (14 percent), entering and cleaning data (16 percent), performing data analysis (40 percent), and writing up summaries of empirical research (5 percent). (See Table 5) Given that duties performed by RAs are logical precursors to research related activities it is not surprising that RAs participate in all research related professional development activities at a higher rate than the TA cohort. Similarly, some of the differences across institution rankings noted above are accentuated for students in RA positions which is not surprising given this is the cohort of students who are more likely to participate in research related activities. While 20 percent of students at second tier schools locate and summarize relevant literature, this is true for only about 7 percent of RAs at top tier schools. On the other hand, about 49 percent of RAs at top tier schools perform data analysis compared to 33 percent of RAs at second tier institutions. (See Table 5.) Given these differences in duties, one might expect to find differences in participation in research-related professional development activities. We find that 54 percent of RAs in top tier institutions have presented in a seminar, 30 percent have submitted to and 15 percent have published in economics journals compared to a consistently lower percentage of RAs in second tier schools participating in these activities, at rates of 39 percent, 25 percent and 8 percent respectively. ${ }^{12}$

Some of the most interesting results are revealed when comparing participation in research-related professional development activities by gender. While there are not large differences between male and female graduate students attending conferences and submitting and publishing in non economics journals, men are slightly more likely than women to present a paper in a seminar and quite a bit more likely to submit to and publish in economics journals. Focusing on the cohort most likely to participate in such activities, we find that 49 percent of male RAs have presented during a seminar compared to only 38 percent of females and about 31 percent of male RAs have submitted a paper to an economics journal compared to about 19 percent of females. ${ }^{13}$ This begs the question as to why these differences might occur. On one hand it might imply self-selection by women in focusing more on teaching related endeavors. Alternatively, it could point to problems with respect to mentoring and that fewer women are encouraged or guided toward submitting papers for publication.

\footnotetext{
${ }^{12}$ Results for these subsamples are not provided in tabular form and are available upon request.

${ }^{13}$ Results for these subsamples are not provided in tabular form and are available upon request.
} 
Table 6 provides insight regarding career aspirations, sources of learning, and thoughts in career advancement for graduate students across various cohorts. Of students at top tier institutions about 56 percent say they will pursue an academic career compared to about 51 percent for students at second tier schools. A far greater percentage of students at top tier schools indicate that in fifteen years they hope to be at a major university (46 percent versus 27 percent), while students at second tier institutions are much more likely to express interest in working at liberal arts colleges (17 percent versus 10 percent) and in the private sector (16 percent versus 8 percent). About 59 percent of students working as TAs say they will pursue an academic career compared to about 53 percent of students working as RAs.

When asked if they will pursue an academic career after graduate school nearly 57 percent of men answer affirmatively compared to about 46 percent for women. In response to the question regarding where they hope to be in fifteen years, about 38 percent of males said they would like to be at a major university whereas only 27 percent of women have the same aspiration. About 14 percent of males aspire to jobs at liberal arts colleges compared to 16 percent of women. The difference in terms of economic policy views were larger. Only 13 percent of males say they would like to end up in an institution directly involved in economic policy decision making compared to a much larger 23 percent of females. This reinforces results found by Colander and Holmes (2007).

In light of concerns about the progress of women through the academic "pipeline" our results suggest that many women might be striving for objectives other than upper echelons of academe to begin with. On the other hand, women might have fewer mentors in the academy and engage in fewer mentoring activities, hence influencing career aspirations and opportunities. Linking these results with those described above suggest that differing career aspirations might also affect investment decisions while in graduate school. Recall that women are less likely than men to lead recitations, but more likely than men to teach their own course without guidance. One would imagine that preparation time is far more significant when teaching one's own course than when leading a recitation and that more time devoted to teaching comes at the expense of time devoted to research endeavors. Also, recall that a smaller percentage of women indicated no preparation for teaching activities, indicating a greater time investment in teaching on the part of females.

Students were also asked where they felt they learned the most about economics. While it should not be surprising that the classroom ranks the highest with about 32 percent claiming they learned the most in that setting, more surprising is the fact that about 14 percent rank their job as a research assistant most highly and about 14 percent rank their job as a teaching assistant most highly. Perhaps reflecting the higher quality student interactions at top tier institutions, we find that about 11 percent of students at top tier schools say they learn the most from discussion with their classmates compared to about 6 percent for second tier counterparts.

Table 6 also indicates how students rate various skills for their importance in career success. It appears that research related skills such as problem solving, mathematical ability, and empirical skills are rated highest while teaching related skills are rated the lowest. This ranking is consistent across all cohorts.

\section{Conclusion}


The results of this study are consistent with many of those gathered from surveys conducted at the departmental level. However, this study differs significantly in that we survey graduate students directly hence adding insights into the nature of graduate student training, satisfaction with preparation, and the aspects of preparation students perceive as valuable in their future careers.

The results presented above provide the impetus for potential program adjustments and initiatives for Directors of Graduate Studies to consider. Graduate students and employers alike realize the value of research skill acquisition, yet participation in such activity is somewhat spotty and one gets the impression that much of this training is a function of a student's advisor or informal networking, rather than formal components of the graduate program. Perhaps a fruitful policy initiative within PhD programs that do not currently do so, is to provide a more formalized structure for research skill training. The importance of such enhancements is even more crucial when one notices that females are receiving this training and participating in related opportunities at a much lower rate which might be a function of an informal acquisition structure rather than a uniform skill acquisition plan. Such efforts might include a graduate student workshop with required graduate participation, subsidized travel to research conferences, the assignment of faculty research mentors even prior to the dissertation and others. Although some programs already have such initiatives, many do not.

It is also interesting to note that while most graduate students expect to end up in an academic position at a major university, where teaching will certainly be a significant component of the job, most students feel that research skill acquisition is most important for career success. This perception is likely to be developed within and reinforced by the culture of departments and our profession rather than an innate sense of importance that the student develops in isolation. One indication of this culture is the fact that department chairs stated that monitoring teaching activities occurs to a greater extent than graduate students seem to experience. The question that remains for future research therefore, is to what extent do the graduate education process and culture encourage research skills and discourage a focus on the development of teaching skills. One could certainly argue that a job market candidate who can demonstrate that they have acquired a set of skills covering both research and teaching is more prepared to join and be a successful participant in the academy of professional educators. As such, this becomes an important question not only for institutions with $\mathrm{PhD}$ programs, but also for institutions that ultimately employ their graduates. 
Table 1

Demographic Characteristics by Cohort

\begin{tabular}{|l|r|r|r|r|r|}
\hline Characteristic & Total & Male* & Female* & \multicolumn{1}{c|}{$\begin{array}{c}\text { Top } \\
\text { Tier* }\end{array}$} & $\begin{array}{c}\text { Second } \\
\text { Tier* }\end{array}$ \\
\hline Gender (number of obs) & 1456 & 940 & 516 & 537 & 894 \\
\hline Male Percentage of sample & 64.56 & & & 64.80 & 64.42 \\
\hline Age (number of obs) & 1452 & 936 & 514 & 536 & 891 \\
\hline Mean Age & 27.94 & 28.15 & 27.57 & 27.11 & 28.40 \\
\hline Race (number of obs) & 1451 & 935 & 514 & 534 & 892 \\
\hline Caucasian & 62.37 & 64.17 & 59.34 & 64.23 & 61.77 \\
\hline African American/Black & 1.65 & 1.39 & 2.14 & 1.12 & 2.02 \\
\hline Hispanic & 7.10 & 8.02 & 5.25 & 7.68 & 6.84 \\
\hline S. Asian (Indo-Pak) & 6.34 & 5.35 & 8.17 & 5.24 & 7.17 \\
\hline East Asian & 13.65 & 11.76 & 16.93 & 13.11 & 13.45 \\
\hline American Indian or Alaskan Native & 0.21 & 0.11 & 0.39 & 0 & 0.22 \\
\hline Middle Eastern & 2.55 & 2.78 & 2.14 & 2.43 & 2.47 \\
\hline Other & 6.13 & 6.42 & 5.64 & 6.18 & 6.05 \\
\hline US Citizen (number of obs) & 1457 & 940 & 515 & 537 & 895 \\
\hline Yes & 50.93 & 52.55 & 48.16 & 49.16 & 52.29 \\
\hline Year in Graduate School (number of obs) & 1450 & 936 & 512 & 536 & 889 \\
\hline First & 23.52 & 25.53 & 19.92 & 22.20 & 24.30 \\
\hline Second & 23.59 & 23.40 & 23.83 & 19.03 & 26.21 \\
\hline Third & 18.07 & 17.63 & 18.95 & 16.98 & 18.79 \\
\hline Fourth & 16.21 & 16.24 & 16.21 & 18.10 & 14.85 \\
\hline >= Fifth & 18.62 & 17.20 & 21.09 & 23.69 & 15.86 \\
\hline $\begin{array}{l}\text { In which of the following activities, besides studying, } \\
\text { are you currently engaged? (Check all that apply) } \\
\text { (number of obs) }\end{array}$ & & & & & \\
\hline Research assistant & 1385 & 894 & 487 & 496 & 863 \\
\hline Teaching assistant & 30.61 & 30.20 & 31.62 & 33.27 & 29.55 \\
\hline Consulting & 51.12 & 52.13 & 49.69 & 48.19 & 52.26 \\
\hline Working on dissertation & 8.74 & 10.07 & 6.37 & 6.45 & 10.20 \\
\hline The writing of scholarly papers for publication & 46.28 & 45.30 & 48.25 & 55.44 & 41.48 \\
\hline
\end{tabular}

Note: The number of observations are provided for each question as not all survey respondents answered each question.

* Percent of total unless otherwise noted 
Table 2

TA Duties, Preparation, and Evaluation

Sample: TA Cohort, 708 obs, $48.53 \%$ (out of full sample of 1459)

\begin{tabular}{|c|c|c|c|c|c|}
\hline Characteristic & Total & Male* & Female* & $\begin{array}{c}\text { Top } \\
\text { Tier* }\end{array}$ & $\begin{array}{l}\text { Second } \\
\text { Tier* }\end{array}$ \\
\hline Category that best describes duties (Number of obs) & 704 & 463 & 241 & 238 & 448 \\
\hline $\begin{array}{l}\text { I am a grader and do not teach either a recitation } \\
\text { section or a class }\end{array}$ & 21.59 & 21.38 & 21.99 & 13.87 & 25.89 \\
\hline I lead recitation sections & 40.77 & 42.55 & 37.34 & 54.20 & 33.26 \\
\hline $\begin{array}{l}\text { I am in charge of my own class(es) with } \\
\text { guidance of an assigned faculty member }\end{array}$ & 10.37 & 10.37 & 10.37 & 10.50 & 10.04 \\
\hline $\begin{array}{l}\text { I am in charge of my own class(es) without } \\
\text { guidance of an assigned faculty member }\end{array}$ & 19.74 & 18.79 & 21.58 & 12.61 & 23.88 \\
\hline Other & 7.53 & 6.91 & 8.71 & 8.82 & 6.92 \\
\hline $\begin{array}{l}\text { How much preparation for teaching did you have? } \\
\text { Check all that apply. (Number of obs) }\end{array}$ & 633 & 426 & 207 & 212 & 407 \\
\hline None & 47.39 & 51.17 & 39.61 & 44.81 & 49.39 \\
\hline $\begin{array}{l}\text { If your primary language is not English, were } \\
\text { you required to take an English proficiency test? }\end{array}$ & 36.65 & 34.04 & 42.03 & 37.74 & 35.87 \\
\hline $\begin{array}{l}\text { A noncredit course taught by the economics } \\
\text { department }\end{array}$ & 18.33 & 17.14 & 20.77 & 23.58 & 15.23 \\
\hline $\begin{array}{l}\text { A for credit course taught by the economics } \\
\text { department }\end{array}$ & 13.11 & 11.50 & 16.43 & 11.79 & 13.76 \\
\hline $\begin{array}{l}\text { Are you satisfied with the level of preparation you } \\
\text { have had for your teaching related duties? (Number } \\
\text { of obs) }\end{array}$ & 620 & 418 & 202 & 209 & 397 \\
\hline I am very satisfied & 46.77 & 48.33 & 43.56 & 40.67 & 49.62 \\
\hline I am somewhat satisfied & 45.00 & 43.06 & 49.01 & 48.80 & 43.32 \\
\hline I am unsatisfied & 8.23 & 8.61 & 7.43 & 10.53 & 7.05 \\
\hline $\begin{array}{l}\text { To what extent is your teaching evaluated? Check all } \\
\text { that apply. (Number of obs) }\end{array}$ & 676 & 449 & 227 & 228 & 432 \\
\hline No formal evaluation performed & 13.91 & 14.48 & 12.78 & 5.70 & 18.75 \\
\hline End-of-term evaluations are used & 81.21 & 81.07 & 81.06 & 91.23 & 75.23 \\
\hline A faculty member visits my class & 14.79 & 15.14 & 14.10 & 18.86 & 13.19 \\
\hline My course materials are reviewed & 4.59 & 5.12 & 3.52 & 2.63 & 5.56 \\
\hline Other please specify & 9.76 & 8.69 & 11.89 & 10.09 & 9 \\
\hline
\end{tabular}

* Percent of total unless otherwise noted 
Table 3

TA Characteristics, Preparation, and Evaluation by Duties

Sample: TA Cohort

\begin{tabular}{|c|c|c|c|c|c|}
\hline Characteristic & Grader* & $\begin{array}{c}\text { Leads } \\
\text { recitation* }\end{array}$ & $\begin{array}{l}\text { Teaches own } \\
\text { class(es) with } \\
\text { guidance* }\end{array}$ & $\begin{array}{l}\text { Teaches own } \\
\text { class(es) } \\
\text { without } \\
\text { guidance* }\end{array}$ & $\begin{array}{l}\text { Total } \\
\text { (includes } \\
\text { "other" } \\
\text { category) }\end{array}$ \\
\hline $\begin{array}{l}\text { Year in Graduate School (Number } \\
\text { of obs) }\end{array}$ & 152 & 286 & 73 & 139 & 703 \\
\hline First & 36.18 & 12.94 & 6.85 & 1.44 & 16.07 \\
\hline Second & 27.63 & 25.87 & 17.81 & 12.95 & 22.48 \\
\hline Third & 18.42 & 29.72 & 24.66 & 20.14 & 24.04 \\
\hline Fourth & 8.55 & 20.28 & 27.40 & 34.53 & 20.77 \\
\hline$>=$ Fifth & 9.21 & 11.19 & 23.29 & 30.94 & 16.64 \\
\hline $\begin{array}{l}\text { How much preparation for } \\
\text { teaching did you have? Check all } \\
\text { that apply. (Number of obs) }\end{array}$ & 134 & 260 & 67 & 126 & 633 \\
\hline None & 61.94 & 41.92 & 28.36 & 48.41 & 47.39 \\
\hline $\begin{array}{l}\text { If your primary language is } \\
\text { not English, were you required } \\
\text { to take an English proficiency } \\
\text { test? }\end{array}$ & 29.85 & 35.00 & 64.18 & 34.92 & 36.65 \\
\hline $\begin{array}{l}\text { A noncredit course taught by } \\
\text { the economics department }\end{array}$ & 11.19 & 25.00 & 14.93 & 19.05 & 18.33 \\
\hline $\begin{array}{l}\text { A for credit course taught by } \\
\text { the economics department }\end{array}$ & 11.94 & 12.69 & 16.42 & 15.08 & 13.11 \\
\hline $\begin{array}{l}\text { Are you satisfied with the level of } \\
\text { preparation you have had for your } \\
\text { teaching related duties? (Number } \\
\text { of obs) }\end{array}$ & 131 & 257 & 66 & 123 & 620 \\
\hline I am very satisfied & 58.02 & 45.91 & 46.97 & 41.46 & 46.77 \\
\hline I am somewhat satisfied & 35.88 & 47.08 & 50.00 & 43.90 & 45.00 \\
\hline I am unsatisfied & 6.11 & 7.00 & 3.03 & 14.63 & 8.23 \\
\hline $\begin{array}{l}\text { To what extent is your teaching } \\
\text { evaluated? Check all that apply. } \\
\text { (Number of obs) }\end{array}$ & 134 & 284 & 72 & 137 & 676 \\
\hline $\begin{array}{l}\text { No formal evaluation } \\
\text { performed }\end{array}$ & 37.31 & 7.75 & 4.17 & 2.19 & 13.91 \\
\hline $\begin{array}{l}\text { End-of-term evaluations are } \\
\text { used }\end{array}$ & 50.00 & 88.38 & 95.83 & 97.81 & 81.21 \\
\hline $\begin{array}{l}\text { A faculty member visits my } \\
\text { class }\end{array}$ & 4.48 & 12.32 & 33.33 & 24.09 & 14.79 \\
\hline $\begin{array}{l}\text { My course materials are } \\
\text { reviewed }\end{array}$ & 2.24 & 1.76 & 8.33 & 11.68 & 4.59 \\
\hline Other please specify & 12.69 & 10.92 & 1.39 & 6.57 & 9.76 \\
\hline
\end{tabular}

* Percent of total unless otherwise noted 
Table 4

Differences in Research Related Activities by Cohort*

\begin{tabular}{|l|c|c|c|c|c|c|c|}
\hline $\begin{array}{l}\text { Percent of total or } \\
\text { identified sub sample }\end{array}$ & Total & $\begin{array}{c}\text { Top } \\
\text { Tier }\end{array}$ & $\begin{array}{c}\text { Second } \\
\text { Tier }\end{array}$ & TA & RA & Male & Female \\
\hline $\begin{array}{l}\text { Extent to which you have } \\
\text { participated in the } \\
\text { following activities }\end{array}$ & & & & & & & \\
\hline $\begin{array}{l}\text { Attended a } \\
\text { professional } \\
\text { economics } \\
\text { conference }\end{array}$ & 56.38 & 55.66 & 57.18 & 57.49 & 59.95 & 55.69 & 57.68 \\
\hline $\begin{array}{l}\text { Attended another } \\
\text { type of conference }\end{array}$ & 45.73 & 39.81 & 49.58 & 43.56 & 48.78 & 45.27 & 46.57 \\
\hline $\begin{array}{l}\text { Presented a paper in } \\
\text { a graduate school } \\
\text { seminar (not a class) }\end{array}$ & 37.38 & 45.90 & 32.28 & 41.75 & 44.95 & 39.12 & 34.29 \\
\hline $\begin{array}{l}\text { Presented a paper at } \\
\text { a professional } \\
\text { economics } \\
\text { conference }\end{array}$ & 21.03 & 20.00 & 21.81 & 19.88 & 25.06 & 21.08 & 21.02 \\
\hline $\begin{array}{l}\text { Submitted a } \\
\text { completed research } \\
\text { paper to an } \\
\text { economics journal }\end{array}$ & 22.33 & 23.85 & 21.69 & 21.23 & 26.99 & 24.06 & 18.69 \\
\hline $\begin{array}{l}\text { Submitted a } \\
\text { completed research } \\
\text { paper to an non } \\
\text { economics journal }\end{array}$ & 11.18 & 8.45 & 12.85 & 7.91 & 14.07 & 11.04 & 11.48 \\
\hline $\begin{array}{l}\text { Published a paper in } \\
\text { an economics journal }\end{array}$ & 10.14 & 11.81 & 9.04 & 9.45 & 10.78 & 11.27 & 7.85 \\
\hline $\begin{array}{l}\text { Published a paper in } \\
\text { a non economics } \\
\text { journal }\end{array}$ & 10.52 & 9.42 & 11.27 & 8.62 & 11.85 & 10.69 & 10.23 \\
\hline
\end{tabular}

* Number of observations vary by cohort and activity 
Table 5

RA Duties by Cohort

\begin{tabular}{|l|r|r|r|r|r|}
\hline Characteristic & Total & Male* & Female* & $\begin{array}{c}\text { Top } \\
\text { Tier* }\end{array}$ & $\begin{array}{c}\text { Second } \\
\text { Tier* }\end{array}$ \\
\hline Category that best describes duties (Number of obs) & 398 & 252 & 146 & 160 & 234 \\
\hline Locating and summarizing relevant literature & 14.32 & 13.49 & 15.07 & 6.88 & 19.66 \\
\hline Entering and cleaning data & 15.58 & 14.68 & 17.12 & 14.38 & 16.24 \\
\hline Performing data analysis & 39.70 & 38.89 & 41.10 & 48.75 & 33.33 \\
\hline Writing up summary of empirical research & 5.53 & 4.37 & 7.53 & 4.38 & 5.98 \\
\hline Other, please describe & 24.87 & 28.57 & 18.49 & 25.63 & 24.36 \\
\hline
\end{tabular}

* Number of observations vary by cohort and activity 
Table 6

Differences in Career Characteristics, Learning, and Advancement Expectations by Cohort

\begin{tabular}{|c|c|c|c|c|c|c|c|}
\hline Characteristic & $\begin{array}{c}\text { Top } \\
\text { Tier* }\end{array}$ & $\begin{array}{c}\text { Second } \\
\text { Tier* }\end{array}$ & TAs* & RAs* & Male* & Female* & Total \\
\hline $\begin{array}{l}\text { Will you pursue an academic career after } \\
\text { graduate school? (Number of obs) }\end{array}$ & 528 & 874 & 693 & 415 & 918 & 503 & 1424 \\
\hline Yes & 56.06 & 50.69 & 59.31 & 52.53 & 56.54 & 46.32 & 52.88 \\
\hline No/Unsure & 43.94 & 49.31 & 40.69 & 47.47 & 43.46 & 53.68 & 47.12 \\
\hline $\begin{array}{l}\text { Where do you hope to be in } 15 \text { years from } \\
\text { now? (Number of obs) }\end{array}$ & 525 & 864 & 682 & 416 & 909 & 498 & 1410 \\
\hline At a major university & 45.71 & 26.85 & 38.42 & 34.86 & 37.84 & 26.91 & 33.90 \\
\hline At a good liberal arts college & 10.48 & 17.48 & 14.81 & 14.42 & 14.30 & 16.06 & 14.89 \\
\hline At a major research institution & 12.00 & 12.15 & 12.17 & 14.90 & 11.55 & 13.05 & 12.06 \\
\hline $\begin{array}{l}\text { At an institution that is indirectly } \\
\text { involved in economic policy making }\end{array}$ & 16.19 & 17.13 & 15.84 & 16.59 & 13.31 & 23.09 & 16.81 \\
\hline In the private sector & 8.00 & 16.44 & 10.85 & 11.54 & 13.42 & 12.25 & 13.05 \\
\hline Other & 7.23 & 9.95 & 7.92 & 7.69 & 9.56 & 8.63 & 9.29 \\
\hline \multicolumn{8}{|l|}{$\begin{array}{l}\text { Where learned most about economics? } \\
\text { (Percentage who ranked option highest) }\end{array}$} \\
\hline In the classroom & 30.15 & 32.92 & 30.77 & 31.19 & 31.14 & 33.19 & 31.88 \\
\hline In seminars & 8.23 & 6.88 & 7.67 & 8.97 & 7.09 & 7.94 & 7.37 \\
\hline $\begin{array}{l}\text { By reading assigned readings on your } \\
\text { own }\end{array}$ & 11.25 & 12.50 & 13.12 & 9.71 & 12.53 & 10.96 & 11.98 \\
\hline $\begin{array}{l}\text { By reading unassigned readings on your } \\
\text { own }\end{array}$ & 11.02 & 12.36 & 9.59 & 10.51 & 14.45 & 7.02 & 11.85 \\
\hline In discussion with other students & 11.42 & 5.76 & 8.80 & 9.21 & 7.94 & 7.99 & 7.95 \\
\hline In your job as a research assistant & 14.41 & 14.38 & 15.42 & 12.44 & 12.76 & 17.46 & 14.38 \\
\hline $\begin{array}{l}\text { Teaching your own course or being a } \\
\text { teaching assistant }\end{array}$ & 12.66 & 15.46 & 12.78 & 17.10 & 14.01 & 15.10 & 14.35 \\
\hline \multicolumn{8}{|l|}{$\begin{array}{l}\text { Which characteristics will most likely place } \\
\text { students on the fast track? (4. Very important; } \\
\text { 3. Moderately important; } 2 \text {. Unimportant; } 1 \text {. I } \\
\text { don't know) }\end{array}$} \\
\hline $\begin{array}{l}\text { Being smart in the sense that they are } \\
\text { good at problem solving }\end{array}$ & 3.46 & 3.53 & 3.51 & 3.52 & 3.51 & 3.50 & 3.51 \\
\hline $\begin{array}{l}\text { Being interested in, and good at, } \\
\text { empirical research }\end{array}$ & 3.37 & 3.43 & 3.40 & 3.49 & 3.34 & 3.53 & 3.41 \\
\hline $\begin{array}{l}\text { Being interested in and good at teaching } \\
\text { economics }\end{array}$ & 2.22 & 2.53 & 2.43 & 2.40 & 2.37 & 2.49 & 2.41 \\
\hline Excellence in mathematics & 3.36 & 3.44 & 3.43 & 3.37 & 3.41 & 3.41 & 3.41 \\
\hline $\begin{array}{l}\text { Being very knowledgeable about one } \\
\text { particular field }\end{array}$ & 3.27 & 3.13 & 3.21 & 3.17 & 3.19 & 3.16 & 3.18 \\
\hline $\begin{array}{l}\text { Ability to make connections with } \\
\text { prominent professors }\end{array}$ & 3.31 & 3.18 & 3.26 & 3.27 & 3.18 & 3.31 & 3.22 \\
\hline $\begin{array}{l}\text { A broad knowledge of the economics } \\
\text { literature }\end{array}$ & 2.85 & 2.96 & 2.89 & 2.96 & 2.86 & 3.02 & 2.19 \\
\hline A thorough knowledge of the economy & 2.48 & 2.80 & 2.67 & 2.67 & 2.59 & 2.84 & 2.77 \\
\hline
\end{tabular}

* Percent of total unless otherwise noted 


\section{References}

Colander, David and Jessica Holmes. 2007. Gender and Graduate Education in the US. Journal of Feminist Economics, 13(2): 93-116.

National Science Foundation. http://www.nsf.gov/statistics/nsf07321/pdf/tab10.pdf

Stock, Wendy A. and W. Lee Hansen. 2004. PH.D. Program Learning and Job Demands: How Close is the Match? American Economic Review Papers and Proceedings, 94(2): 266-271.

Stock, Wendy A., T. Aldrich Finegan, and John J. Siegfried. 2006. "Attrition in Economics Ph.D. Programs." American Economic Review Papers and Proceedings, 96(2): 458-466.

Thursby, J.G. 2000. What Do We Say about Ourselves and What Does It Mean? Yet Another Look at Economics Department Research. Journal of Economic Literature, 38(2): 383-404.

U.S. News and World Report. 2005. America’s Best Graduate Programs in Economics. http://www.usnews.com/usnews/edu/grad/rankings/phdhum/brief/ecorank_brief.php

Walstad, William B. and William E. Becker. 2003. “The Instructional Use and Teaching Preparation of Graduate Students in U.S. Ph.D.-Granting Economics Departments. American Economic Review Papers and Proceedings, 93 (2), pp. 449-454. 